\title{
Külkedisi Masalını Yeniden Yazmak: Külprensi ile Vejetaryen Külkedisi Adlı Resimli Kitapların Karşılaștırmalı İncelemesi
}

\section{Rewriting the Cinderella Tale: A Comparative Review of Prince Cinders and Vegetarian Cinderella Picture Books}

\author{
Merve Esra ÖZGÜRBÜZ1
}

'Dr., Karadeniz Technical University, Faculty of Letters, Department of Turkish Language and Literature, Trabzon, Türkiye

ORCID: M.E.O. 0000-0002-0616-5071

\section{Corresponding author:}

Merve Esra ÖZGÜRBÜZ

Karadeniz Teknik Üniversitesi, Edebiyat Fakültesi, Türk Dili ve Edebiyatı Bölümü,

Trabzon, Türkiye

E-mail: mervesrapolat@gmail.com

Submitted: 30.01 .2021

Revision Requested: 29.05.2021

Last Revision Received: 29.05.2021

Accepted: 31.08 .2021

Citation: Ozgurbuz, M. E. (2021). Külkedisi masalını yeniden yazmak: Külprensi ile Vejetaryen Külkedisi adlı resimli kitapların karşılaştırmalı incelemesi. Litera, 31(2), 757-782.

https://doi.org/10.26650/LITERA2021-871307
Öz

Toplumun normlarını bilinçli şekilde genç dimağlara aşılamaya araç olan masallar; bilinçaltında, tarafı ıir yaşam senaryosu için çok sayıda klişeleşmiş rol, konum ve eylem değerine yol açmaktadır. Bu çalışmada, Külkedisi masalııın özgün dokunuşlarla yeniden yazıldığı, bakış açısının değiştirildiği, cinsiyetçilik, güçsüzlük gibi algıların yapıbozuma uğratıldığı Külprensi ve Vejetaryen Külkedisi adlı resimli kitaplar odağında postfeminist bir çözümleme hedeflenmektedir. Iki farklı edebiyattan seçilen, aralarında yirmi iki yıllık zaman farkı bulunan, toplumsal cinsiyet kurgularını farklı yaklaşım ve daha eşitlikçi bir perspektiften yansıtan eserlerde; ikiliklere dayandırılan pozisyonların mutlaklığı sorgulanacak, köktenci yapılarla mücadele edilirken klişeler üretilip üretilmediği tartışılacak ve yeniden yazım sürecinde tespit edilen benzerlik ve farklııklar üzerinde durulacaktır. Çalışmanın özgün değeri; tek yönlü çocuk yetiştirme temayülünü besleyen klasik masalların, resimli çocuk kitapları aracılığıyla postyapısalcı yöntemlerle yapıbozuma uğratıldığının tespiti ve çok boyutlu kavramlar merkezinde mutlak ve ideal addedilen durumların reddedildiğinin, cinsiyetler arasında insan eliyle yaratılan sınırların belirsizleştiğinin ortaya konulmasıyla çoğulcu kültürel bir karşılaştırmanın mümkün kılınmasıdır. Çalışmanın teorik çerçevesini, tüm mağduriyetleri üstlenen postfeminizm; metodunu postyapısalcı teorilerin yöntemi olan yapıbozum ile çözümlenen resimli kitapların derin yapısına ulaşmak ve söylem çözümlemesini yapmak için kullanılan metinlerarasıı ık ve göstergelerarasılık oluşturmaktadır. Çalışmada anlamı derin yapıdan çıkararak metnin ve resmin açık açık söylemese de varsaydıklarını ya da ima ettiklerini tespit etmek için yorumlayıcı bakış açısıyla metin ve resim odaklı çözümleme yapılacaktır. Çalışmanın amaçladığı yaygın etki, yazııı ve görsel bir uyaran olarak öne çıkan resimli kitapların empoze edilen eril tahakkümü reddettiğinin ortaya konulmasıyla farkılıı fikrine vurgu yapılması, eşitlik yerine özerklik kavramının konularak farklı düşünme, farklı tercihlerde bulunma ve farklı olabilme hakkının talep edilmesidir. Anahtar Kelimeler: Çocuk edebiyatı, Külkedisi masalı, resimli çocuk kitabı, postfeminizm, yapıbozum

\section{ABSTRACT}

Fairy tales, which are tools to consciously convey the norms of society to young minds, lead to many stereotypical roles, positions, and action patterns. This study analyses 
the picture books Prince Cinders and La Cenicienta Que No Quería Comer Perdices (literally translated as Cinderella Who Wouldn't Eat Partridges, but given the title Vegetarian Cinderella in the Turkish version) with a postfeminist focus. In these books, which were written twenty years apart and from two types of literature, the tale of Cinderella is rewritten with original touches, the viewpoint is changed, and perceptions such as sexism and powerlessness are deconstructed. In the books, the validity of binary structures is questioned, and this article discusses whether clichés are produced while challenging radical situations. In addition, the similarities and differences detected during the rewriting process will be emphasized. The theoretical framework of the study is postfeminist theory; the methods of the study are deconstruction, which is a poststructuralist method, intertextuality and intersemiotics. In the study, text and picture-oriented analysis will be used from an interpretative perspective to determine what the text and picture assume or imply, even if this is not explicitly said. The widespread impact of the study is to emphasize the idea of difference by demonstrating that picture books reject imposed masculine domination and demand the characters' right to think differently, make different choices and be different by substituting the concept of autonomy for equality.

Keywords: Children's literature, the tale of Cinderella, children's picture book, postfeminism, deconstruction

\section{EXTENDED ABSTRACT}

This study sheds light on how patriarchal hegemony was represented through a comparative analysis of two picture books within the framework of the postfeminist theory. The modern rewritings of the tale of Cinderella from English and Spanish picture books are examined to discuss their approaches towards gender, sexual orientation, and the classical narrative structure of fairy tales. Two picture books, Prince Cinders in English and La Cenicienta Que No Quería Comer Perdices (which literally means Cinderella Who Wouldn't Eat Partridges, and given the title Vegetarian Cinderella in the Turkish version) in Spanish are influenced by the socio-cultural and political environment of the post-1980s period. They undermine binary gender constructions and gender performativity (acting and actions restricted by gender norms) by fictionalizing characters such as the prince, the princess, the king, and the queen contradictory to the classical version of Cinderella. Despite the extensive work on adult literature through the perspective of gender studies, the analysis of picture books addressing children or adults is an understudied field in many respects. Therefore, the aimed questions of this study, which not only contribute to Turkish literature studies but also introduce and analyse these picture books from two works of literature, are as follows: How do feminist movements reflect on classical texts of children's literature, which produces and propagates the male-dominated ideology? In reproducing answers, approvals, and critiques from the classical texts, how have the children's books written from the viewpoint of feminist movements positioned themselves? If changes occur, do they reproduce a similar hierarchical structure? What kind of answer is formulated towards the clichés, and to what degree do the classical and their rewritten text versions differ from each other in the construction of gender? Do these picture books use feminine 
language, that deconstructs the dichotomies built based on contrasts and hierarchies? Do the texts and images show gender equality concerns? Are the texts a description of the pictures? Is children's literature that provides autonomy to children being promoted? These hypotheses, which will be discussed with a multicultural postfeminist analysis, will bring about a new discussion into the literature and reveal that the binary construction of gender representations is no longer valid or that reversed gender roles have been formed contrary to classical texts that are favoring the woman.

This study concludes that the values matched with characters and actions in the picture books named Prince Cinders and Vegetarian Cinderella create alternative subject positions by rejecting stereotypical narrative strategies. In both works, the basic rules of children's literature are transformed with creative and innovative uses, and the necessity of being beautiful, handsome, weak, muscular, or young, which is attributed to gender, is criticized. In contrast to the rescue of the princess by the prince in the original text, her unique existence is emphasized. Thus, it is possible to say that the two texts challenge the patterns of the classic fairy tale, that is, with the gendered traditional qualities. However, Prince Cinders reproduces a similar hierarchical structure while transforming the original text Cinderella tale on the axis of gender fiction. In other words, while it can be claimed that the Vegetarian Cinderella represents a break from the fairy tale tradition in the context of the original text, Prince Cinders maintains the hierarchical structure even though it has changed the fiction within the framework of gender stereotypes, and instead of hegemonic masculinity in the original text, it establishes hegemonic femininity. Prince Cinders criticizes character representations shaped by binary oppositions and features considered masculine in patriarchal ideology. At the same time the book highlights a physical standard, the inability of the character to act without the help of a fairy, finding each other by chance, a happy life with marriage, and punishing evil brothers, thus negatively constructing a situation with homosexual characteristics and maintaining the hierarchy created between jobs, all of which are indications that Prince Cinders produced a similar structure to the original fairy tale. The postfeminist analysis of these two picture books with images and short texts exemplifies that although they have a common point, which was to undermine the hegemonic masculinity, their methods differ from each other in so doing. 


\section{Giriş}

Çalışmada İspanyolca ve İngilizce edebiyattan seçilen örneklem çerçevesinde toplumsal cinsiyet, cinsel yönelim ve masal kurgusunda işleyen mekanizmalar ve söz konusu mekanizmaların yapıbozuma uğratılması, dönüştürülmesi veya benzer mekanizmanın yeniden üretilmesi detaylıca incelenmektedir; çünkü eril hegemonyanın inşa ettiği sistemin ne şekilde sekteye uğratıldığı ya da uğratılamadığı çalışmanın değindiği temel meseledir. 1987 ve 2009 yıllarında ilk baskılarını yapmış olmak üzere 1980 sonrasının kültürel, sosyokültürel ve politik yapısından etkilenen iki eserin tercih edilmesinin nedeni, bu dönemde çocuk edebiyatının geleneksel olanın ötesine geçerek toplumsal kuralların, düşünce yapısının ve kalıpların sorgulanmasına imkân vermesi ve toplumsal klişelerin sorgulandığı kültürlerarası karşılaştırmalı bir analizin yapılabilmesidir. Resimli kitaplarda yazının desteği olmaksızın çocukların öyküler yaratmasına imkân veren semboller aracılığıyla da disiplinler arası bir çalışma mümkün kılınmaktadır. Bununla beraber resimli kitap özelinde çocuk edebiyatı çalışmalarının farklı kuramlarla desteklenerek alanda faklı bakış açılarıyla çözümlemeler yapılması, tek boyutlu bakış açılarının kırılmasına yardım edecektir.

Külkedisi masalının anlatı kalıplarını yıkarak verilen mesajı dönüştüren ve klişelere eleştirel biçimde yaklaşan iki metin; ikili karşıtlıklar odağında kurgulanan prens, prenses, kral ve kraliçe gibi karakterleri benzer olmayan formlarda sunarak cinsiyetlerin performatif alanları ile eril dili yapıbozuma uğratmaktadır Çocuk edebiyatına eleştirel bir gözle bakan bu çalışmanın esas önemi, orijinal masalın klasik kurgusundan sapan yazar ve çizerlerin eserlerinin postfeminist yöntemle karşılaştırmalı şekilde inceleyerek literatüre katkı sağlamaktır. Gençlik edebiyatında ergene dair toplumsal cinsiyet perspektifinde çalışmalar' yapılmasına rağmen çocuk edebiyatı alanında yeterli çalışma yoktur. Dolayısıyla çalışmada kullanılan kuram ve metotlarla karşılaştırmalı olarak çözümlenmemiş örneklem seçimiyle sadece Türkçe değil, uluslararası literatüre de katkı sağlamak amacıyla gerçekleştirilen araştırmanın hedef soruları genel hatlarıyla şöyledir: Feminist hareketler, erkek egemen ideolojinin kendini üretmesi ve sürdürmesinde rol oynayan çocuk

1 Kathryn James'in Death, Gender and Sexuality in Contemporary Adolescent Literature, Kimberley Reynolds'ın Radical Children's Literature: Future Visions and Aesthetic Transformations in Juvenile Fiction, Roberta Seelinger Trites'ın Twenty-first-century Feminisms in Children's and Adolescent Literature adlı kitaplarını, Mary Hilton ile Maria Nikolajeva'nın editörlüğünü üstlendikleri Contemporary Adolescent Literature and Culture isimli çalışmayı, Kathryn Jacobs'ın "Gender Issues in Young Adult Literature", Julia J Motes'in “Teaching Girls to be Girls: Young Adult Series Fiction", Perry Nodelman'ın "Who the Boys Are: Thinking About Masculinity in Children's Fiction" başlıklı makalelerini gençlik edebiyatında ergene dair toplumsal cinsiyet perspektifinde yapılan çalışmalar arasında göstermek mümkündür. 
edebiyatına nasıl yansımaktadır? Feminist hareketlerle beraber toplumsal cinsiyet rollerine uygun yazılan çocuk kitapları ne kadar değişmiş ya da dönüşmüştür? Söz konusu değişim/dönüşüm benzer hiyerarşik yapıyı yeniden üretmekte midir? Değiştirme ve dönüştürme yerine klişeler yeniden üretilip eleştirilen eril kurgu sürdürülerek gelenek mi takip edilmiştir? Eserlerde zıtlıklar ile hiyerarşiler temelinde inşa edilen dikotomileri yapıbozuma uğratan dişil dil kullanılmakta mıdır? Metinler ve resimler cinsiyet eşitliği endişesi sergilemekte midir? Metinler, resimlerin açıklaması niteliğinde midir? Çocuklara özerklik, konuşma ve duyulma yetkisi veren çocuk edebiyatı teşvik edilmekte midir? Çok kültürlü bir postfeminist analizle ele alınacak olan bu hipotezler, literatürde yeni bir tartışmayı beraberinde getirecek ve cinsiyet temsillerinin ikili kurgusunun daha fazla geçerli olmadığı veya farklı şekillerde yeniden üretildiği ortaya konulmaya çalışılacaktır.

Klasik kabul edilen Külkedisi masalının değişime uğratıldığı ya da sürdürüldüğü noktaları tespit etmek için kullanılan kuramsal çerçeve, marjinalleştirilen bütün kimliklerin sesi olan postfeminizmdir. Özellikle ikinci ve üçüncü dalga feminizme eleştirel yaklaşan kuram; ikili düşünceleri, özcü yaklaşımları, toplumsal cinsiyet klişeleri ile mutlak cinsellik vizyonlarını sorgulayarak reddeder. Çalışmanın yöntemi, söz konusu sorgulamayı mümkün kılan ve postyapısalcı teorilerin metodu olan yapıbozumdur. ${ }^{2}$ Dilin ideolojik bir aygıt olduğunu felsefî bir yaklaşımla gösteren, kavramları belli kalıplara oturtmayı reddeden, hiyerarşik düşünme sistemlerine zarar veren, felsefenin kendi içinde taşıdığı çelişkilerin, anların ve aporiaların açığa çıkarılmasını içeren bir dizi hareket olan yapıbozum, anlamların iktidarına karşı çıkarak alt anlamları görünür kılar. Bu yöntem; resmin eşzamanlı taşıdığı gerçek, sembolik, ikonik, linguistik, kodlanmış ve kodu çözülmüş mesajların anlaşılması ve algılanmasına yönelik farklı ve çoğulcu bakış açıları sunduğu için görsel çözümleme kısmında da tercih edilmektedir. Metinlerarasılık ve göstergelerarasılık incelenen eserlerin derin yapısına ulaşmak ve söylem çözümlemesini yapmak için kullanılan yöntemler arasındadır.

2 Çocuk edebiyatı çalışmalarında aynı yöntem Margery Hourihan tarafından Deconstructing The Hero: Literary Theory and Children's Literature adlı çalışmada kullanılmıştır. Hourihan'a göre Batı toplumunda insana ve doğaya uygulanan şiddeti azaltmak ve adalet duygusunu güçlendirmek için çocuklara farklı hikâyeler anlatılmalıdır. Bunu yaparken kahramanın hikâyesi ile okuru çeken özellikleri üzerine ayrıntılı düşünülmeli ve anlatı yapıbozuma uğratılarak yapının nasıl işlediği görünür kılınmalıdır. Hiçbir metnin masum olmadığını, tüm hikâyelerin ideolojik olduğunu savunan postyapısalcı edebiyat teorisi, söz konusu görev için araçlar sağlamaktadır (Hourihan, 1997, s. 4). 


\section{Külkedisi Masalını Feminist Bakış Açısıyla Yeniden Yazmak}

Masalların toplumsal yapıdaki varlığı, farklı kuşakların gelişiminin temel unsurlarından biridir. İçlerinde depolanan bilgiler popüler kültüre nüfuz eder ve kolektif bilinçdışının bir parçası olarak konumlanır. Klasik masallar, bilinçli ya da bilinçsiz şekilde yeniden üretilen bir dizi davranış kalıbı içerir. Tarih boyunca en çok tekrarlanan masallardan biri Külkedisi'dir ve en iyi bilinen modern versiyonları (Perrault veya Grimm), toplumsal cinsiyet dayatmalarının oluşumunda etkisi olan belirli özelliklere sahip bir karakter gösterir. Öyle ki Colette Dowling ilk kez 1982'de yayımlanan Sindrella Kompleksi: Çağdaş Kadında Bağımsızlık Korkusu, adlı kitabında Sindrella kompleksini yaşamlarını sürdürmek ve sorunları çözmek için prenslerini beklemek zorunda kalan bazı kadınların gösterdiği davranış olarak tanımlamaktadır. Ona göre kadınlar otantik varoluşa soyunmanın gerginliğinden kaçmak için boyun eğen bir rolü tercih etmektedir. Erkeksi ve kadınsı sınıflandırmalarının baskın olduğu ve içselleştirildiği düzende alışveriş yapmak, süslenmek, iyi bir eş olmak; kendi başının çaresine bakan yetişkin yaşamından daha az kaygı vericidir (Dowling, 1994, s. 13).

Halkbilimciler tarafından Külkedisi masalının dünya çapında tanımlanan farklı olay örgüsü motiflerine rağmen bu masallarda iddia edilen evrensel anlamlar ekseriyetle benzeşmektedir. Masalın öne çıkan versiyonlarından biri 1697 yılında Cendrillon ou la Petite Pantoufle de Verre adı altında Charles Perrault tarafından Fransızca yazılmıştır. Masalının popülaritesi; yazarın balkabağı, peri-vaftiz annesi ve cam terlik gibi hikâyeye yaptığı eklemelerden kaynaklanmaktadır. Ahlakın ve güzelliğin öne çıktığı masalda zekâ, cesaret, kendini geliştirme, empati kurma gibi özellikler vurgulansa dahi bunların hiçbiri bir perinin yardımı olmadan kişiye mutluluk ve başarı getirmemektedir (Lang, 1889, s. 70).

Külkedisi'nin bilinen bir diğer versiyonu XXI. yüzyılda Alman Jacob ve Wilhelm Grimm tarafından yazılan ve külkedisi anlamına gelen Aschenputtel adlı masaldır. Bu versiyon, Perrault'nun masalına kıyasla daha fazla şiddet ögesi barındırmakta ve çocuklar için tasarlanmadığının ipuçlarını olay örgüsü boyunca vermektedir. Örneğin; üvey kız kardeşler altın terliği giyebilmek için ayaklarının bazı bölgelerini kesmekte ve masalın sonunda Külkedisi tarafından kör edilerek cezalandırılmaktadır. Bahsi geçen versiyonda Külkedisi'nin dilekleri, peri-vaftiz anne yerine annesinin mezarına diktiği dilek ağacı tarafından gerçekleştirilmektedir. Bununla beraber Grimm Kardeşler masalı düzenlemeye devam ederken iyi kadın kategorisinde değerlendirilen Külkedisi ile ölmüş annesine giderek daha az söz hakkı tanırken erkekler ve kötü kadınların konuşma ivmesi 
artmaktadır. Ruth B. Bottigheimer'a göre Grimm Kardeşler için sessizlik, cinsiyete bağlı ahlaki bir durumdur. Iyi kadınlar erdemli karakterlerini sessizlik ve pasiflikle gösterirken kötü kadınlar, kadınca ve dolayısıyla olumsuz olan çok konuşmayla kişiliklerini açığa vurur. Güçlü ve aktif erkekler ise istedikleri gibi konuşma hakkına sahiptir. Külkedisi'nin sessizliğinin ödülü ise prensin eşi olmaktır (Bottigheimer, 2009, s. 51).

İstismar karşısında uysallık ile pasifliğin öne çıkarıldığı masalda özünde bir değer sistemi barındırmayan Külkedisi, kendi yazgısında aktif bir karakter değildir. Ona yardım eden peri-vaftiz anne ya da dilek ağacı olmadan baloya bile katılmaktan acizdir. Güzelliği, kötülüğe sessiz kalışı ile pasifliğinin mükâfatı ise onu prenses yapacak bir erkekle evlenmektir. Külkedisi'nde olduğu gibi güzel prensesler ve yakışıklı prenslerle ilgili geleneksel masallar, benzer anlatı yapılarına sahiptir ve çocuklara Batı kültüründeki en etkili evlilik senaryolarını sağlamaktadır. Ataerkil evlilik kurumu altındaki prensesler, neredeyse her zaman prenslerle evlenir ve sonsuza dek mutlu bir şekilde prensleriyle yaşamak için evlerinden ayrılır. Ancak prenses, prensiyle evlenmek için yakışıklı, cesur ve zeki olan prens tarafından kurtarıldığı zorluklardan geçmek zorundadır. Hikâyenin kapanışında gerçekleşen prens ile evliliği onun mutluluğunun anahtarıdır. Dolayısıyla kadın-erkek temsillerinde bakış açıları kesişen geleneksel masal motifleri, geleceğin yetişkinleri addedilen çocukların örtük ve açık amaçlara ulaştırılması için anlatıların ideolojik diktelerle yönlendirildiğinin kanıtı olarak türün cinsiyetçi yapısını gözler önüne sermektedir. Külkedisi'nin yeniden yazılmasıyla masalın biçim ve içerik unsurlarında barındırdığı cinsiyetçi potansiyeli açığa çıkarmak mümkündür.

Algıları, dolayısıyla hayatları değiştirmeye yardımcı olma potansiyeline sahip masallar; çocuğun benlik kavramını, akranları ve yetişkinlerle etkileşimini etkilemekte, klişeleri teşvik etmek veya ortadan kaldırmak için kullanılmaktadır. Aşırı indirgenmiş cinsiyet rolü stereotiplerini fark eden feminist hareketle beraber okuyan, yazan ve düşünen bireyler çeşitli konuları ve disiplinleri sorgulamaya sevk edilir; tüm insanlara saygı duyan ve zihinleri özgür bırakan bir dünya yaratılmaya çalışıı. Masallarla bilinçaltının normatif ilkeler doğrultusunda şekillendirildiğini öne süren yazarlar, hedef kitleye sunulan düşünceleri değiştirmek için onları yeniden yazmaya başlar. Böylelikle masalların mutluluk hikâyeleri anlatan maskesi ile gizliden gizliye yürüttüğü ideoloji aşılama boyutlarına değinilerek hedef kitle yanlı yönlendirmeler hususunda bilinçlendirilmeye çalışılır (Baykal, 2012, s. 138). Kadının dünyada olma misyonunu erkeğini bulma üzerine kurmuş olan yaklaşımın odağında çocuk edebiyatının cinsiyetçi yapısını reddeden ve temel hikâyenin farklı bir ortam, zaman ve karakter kurgusundan nasıl etkileneceğini 
keşfeden feminist yeniden yazımlarda, cinsiyet ve cinselliğe dair hegemonik normlar dönüştürülerek ataerkil ideolojide kadınsı ve erkeksi şeklinde kodlanan tavırlar yapıbozuma uğratılır; geleneğe başkaldıııır ve cinsiyetsiz bir alan yaratııı. Bu alan; feminist metnin, öncel masalın revizyonu aracılığıyla sağlanan ideolojik amacı ile çok bilinen versiyonların parodisi pozisyonunda geleneksel mesajlar ile yeniden yazımın ironik duruşu arasındaki uyumsuzluklarda ortaya çıkmaktadır.

Edebiyat, illüstrasyon, müzik, tiyatro, bale, opera, film ve diğer medyada yeniden anlatılan, dünyadaki kültürel ve ulusal bağlamlarda içselleştirilerek uyarlanan Külkedisi masalı; farklı sanat ve geleneklerde sürekli olarak yeniden keşfedilmektedir. Külkedisi'nin klasik versiyonları ve onları şekillendiren dinamikler ile modern dönemdeki yeniden yazımları analiz etmek; masalın edebî versiyonlarının tarihsel ve kültürel bağlamları ile bunların ardışık dönüşümlerinin ortaya konulmasını sağlamaktadır. Feminist bakış açısıyla kurgulanan hikâyenin yenilikçi ve cüretkâr yeniden yazımları; masalın sembolik dönüşümleri, metin ve imge arasındaki etkileşim ve masalın ikonografik geleneğinin yenilenmesiyle okura keşfedilecek yeni bir hikâye sunmaktadır.

\section{Farklı Kültürler, Farklı Sesler, Farklı Külkedileri}

Babette Cole tarafından yazılan ve resimlenen Külprensi adlı eser, klasik masala mizahi bir dil ile farklı bir bakış açısı getirmektedir. Toplam otuz iki sayfadan oluşan ve ilk baskısı 1987 yılında yapılan eser kuşe kâğıda basılmış ve ofset baskı tekniğiyle üretilmiştir. Türkçeye çevirisi Coşkun Şenkaya tarafından yapılan resimli kitap, Kuraldışı Yayınları tarafından 2014 yılında Türkiye'de yayımlanmıştır.

Külprensi (Prince Cinders) ismi, ironik şekilde orijinal masaldaki başkahramanın cinsiyetinin değiştiğini vurgulamaktadır. Kül ifadesi öncel metni anıştıırken prens hem statü hem de cinsiyet bakımından farklı bir anlam dünyasını çağrıştırmaktadır. Kül ve prens kelimelerinin birlikteliği ise karşıt iki simgenin bir arada kullanılmasıyla dikotomik kurgunun daha başlıkta yapıbozuma uğratılmaya başlandığı manasına gelmektedir. Başlıktaki değişim ve ironiyi desteklemeye devam eden, beyaz renkle ve büyük harflerle yazılan Külprensi ifadesinin hemen altında yer alan kapak resminin dikdörtgen bir çerçeve içine alınması, olay örgüsünün geçtiği dünya ile ilgili sınılı bir göstergenin olduğu anlamına gelmektedir (Moebius, 1988). Koyu mavi bir arka planda iki boyutlu sarışın ve sıska bir erkek figürü gece vakti telaş içinde koşarken resmedilmektedir. Figürün başında altından bir kraliyet tacı varken üstündeki beyaz iş önlüğü, her tarafı 
yırtılmış çorapları, bir hayli eskimiş olan ve koşarken üstünden düşen pantolonu eşzamanlı bir uyumsuzluğun göstergeleridir. Öncel metinde balo mekânından hızla uzaklaşan Külkedisi camdan yapılmış ayakkabısının/terliğinin bir eşini düşürürken Külprensi'nin pantolonunu düşürmesi hem mizahi hem de yapıbozumcu bir yaklaşımdır.

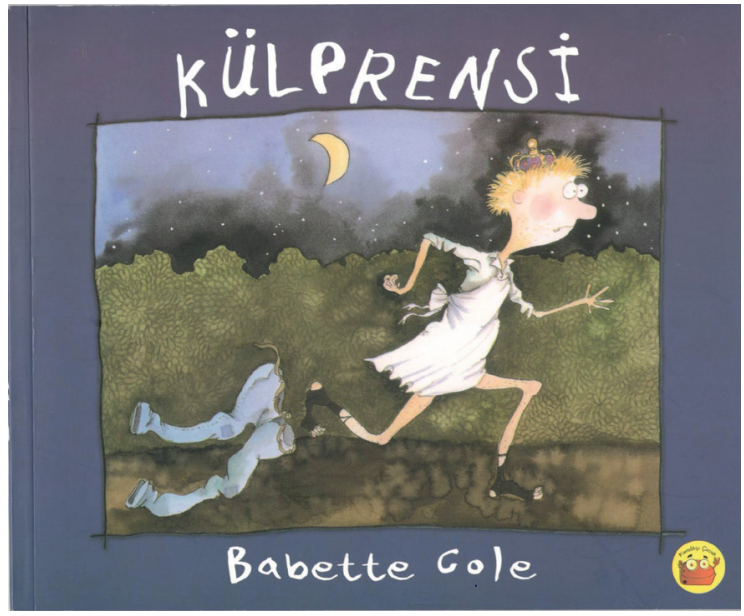

Resim 1: Külprensi

Klasik Külkedisi masalının içeriğinde orijinal yapıyı sarsan değişiklikler yapılarak sunulduğu ve kardeşlerinin eziyet ettiği kurtarılmaya muhtaç karakterin bu defa erkek olarak tanımlandığı/yer aldığı eserde, klasik olay örgüsünün ana hatları takip edilse dahi tüm cinsiyet rolleri tersine çevrilmekte ve öncel masala yeni bir bakış açısı getirilmektedir. Kötü muamele gören kızın yerinde iri ve kıllı üç ağabeyinin arkasını temizlemek için sabah akşam iş yapan ve maço olmadığı için onlar tarafından dışlanan "ufak tefek, sivilceli, pasaklı, sıska" (2016) ve sarışın bir erkek vardır. Ağabeyleri gibi diskoya gitmek istediğinde henüz büyülerin formülünü tam bilmeyen genç bir kadın olan peri; Külprensi'ni iri, kıllı bir maymun olarak minicik kırmızı bir arabayla partiye gönderir. Külprensi, cüssesi sebebiyle diskoya giremez ve geri dönmek üzere durağa yönelir. Durakta otobüs beklerken maymun görünümündeki Külprensi'yle karşılaşan prenses, onu korkutucu bulur.Vakit gece yarısını geçtiğinde Külprensi büyü öncesindeki hâline dönüşür ve prenses onun kendisini büyük kıllı maymundan kurtardığını düşünür. Külprensi, prensesten kaçarken hikâyenin cam terliği hâline gelen pantolonunu düşürür. "Zengin ve güzel Prenses Şekerkuruş" (2016), kayıp pantolonun sahibini bulmak için ilan verir. Denemeler sonunda Külprensi dışında kimse pantolona sığamaz. Böylelikle prenses Külprensi'yle evlenir. Kıllı ağabeyler ise prensesin isteği ve perinin yardımılla ev temizliği perilerine dönüştürülerek cezalandırıır. 
Teşekkür kısmında Külprensi'nin feminist yazarı Babette Cole'e başka masallar anlatılmasında yardımcı olduğu için teşekkür edilen Vejetaryen Külkedisi adlı resimli kitabın yazarı Nunila Lopez Salamero, çizeri ise Miriam Cameros Sierra'dır. İlk baskısını 2009 yılında yapan kitap 72 sayfadan oluşmaktadır. Zekine Sanchez Veiga tarafından Türkçeye çevrilen eserin bu dildeki ilk baskısı 2012 yılında Nota Bene Yayınları tarafından yapılmıştır. Ofset baskı tekniğiyle üretilen eserin hamur kalitesi 1. sınıf kuşe kâğıttır ve metin kısmı, çalışmada incelenen ilk kitaba kıyasla daha hacimlidir. Kitabın ön kapağında beyaz renkle ve büyük puntolarla yazan Vejetaryen Külkedisi adlı başlık, külkedisi kelimesiyle öncel masalı hatırlatırken vejetaryen nitelemesiyle eserin marjinal yanını ortaya koymaktadır.

Vejetaryenlik, yeme şekilleri ile kimlik arasındaki ilişkiyi keşfetmenin bir yolunu sunmaktadır. Carol J. Adams, Etin Cinsel Politikası adlı çalışması boyunca ataerkil kültürün hayvanların yenmesini nasıl onayladığını açıklayarak örtük çağrışımları ifşa eder ve böylece feminizm ile vejetaryenliğin yollarının kesiştiği noktaları tespit eder. Yazara göre erkeklik inşasının önemli bir parçası, başka bedenleri denetim altında tutmaktır ve et yemek söz konusu inşanın hayati bir aşamasını oluşturur. Reklamlarda eti yenen hayvanların kadınsı temsil edilmesi ve erkek zihninde seks yapılacak kadının et veya piliç görüntüsünde olması dahi ataerki ile et tüketimi arasındaki diyalektiği çözümlemekte ve beslenme şekilleri aracılığıyla kimlikler arasında yaratılan ayrıma işaret etmektedir (Adams, 2021, s. 47-56). Bedenin ve çevrenin fiziksel, psikolojik, duygusal ve kavramsal yönleri ile dönüşlü etkileşimlerinden veya birleşimlerinden ortaya çıkan ve bu ilişkilerin bütünü içinde oluşan kimlik (Fox, 2002, s. 348); cinsiyet ve cinsellik gibi konularda dönüşlü bir beden için alternatifler sağlar ve kimliğin sınırları bir bedenin neler yapabileceğinin bağlamları içinde ortaya çıkar (Fox ve Ward, 2008, s. 2586). Hem diyet hem de bedensel bir uygulama ve mücadele olan vejetaryen kimlikte birtakım motivasyonlar ön plandadır. Kişisel sağlık ve hayvanları koruma (Lea ve Worsley, 2001, s. 127), et yemeye karşı geliştirilen duygusal tepkiler (Kenyon ve Barker, 1998, s. 187), et ve ataerkillik (Adams, 2021), katliam güdüsü ve erkeklik (Twigg, 1979, s. 17) gibi özellikle etik vejetaryenliği içeren motivasyonlar; hümanist ideolojilere dayanmaktadır. Etik vejetaryen, yiyecek veya diğer nedenlerle hayvanlara verilen zararı en aza indirmek isterken (Fessler, Arguello, Mekdara ve Macias, 2003, s. 31) ataerkil dayatmanın ilkelerine karşı çıkar. Zira vejetaryenlik sadece yemeğe karşı bilişsel bir yanıt değil, aynı zamanda kimliğe işaret eden somutlaşmış bir uygulamadır. Somutlaştırma üzerine yapılan son çalışmalar, bedenin sosyal düzen ve organizasyonun birçok yönüne aracılık edebileceğini ve insanların refleks olarak kimliklerini nasıl inşa ettiklerine katkıda bulunabileceğini 
göstermektedir (Fox ve Ward, 2008, s. 2588). Dolayısıyla akışkan ve öznel bir kategori pozisyonunda öne çıkan Vejetaryen Külkedisi kimliği, yiyecek seçiminin insanların kişisel ve felsefî taahhütlerini ifade etmeleri için başka bir yol şeklinde ortaya konulmaktadır.

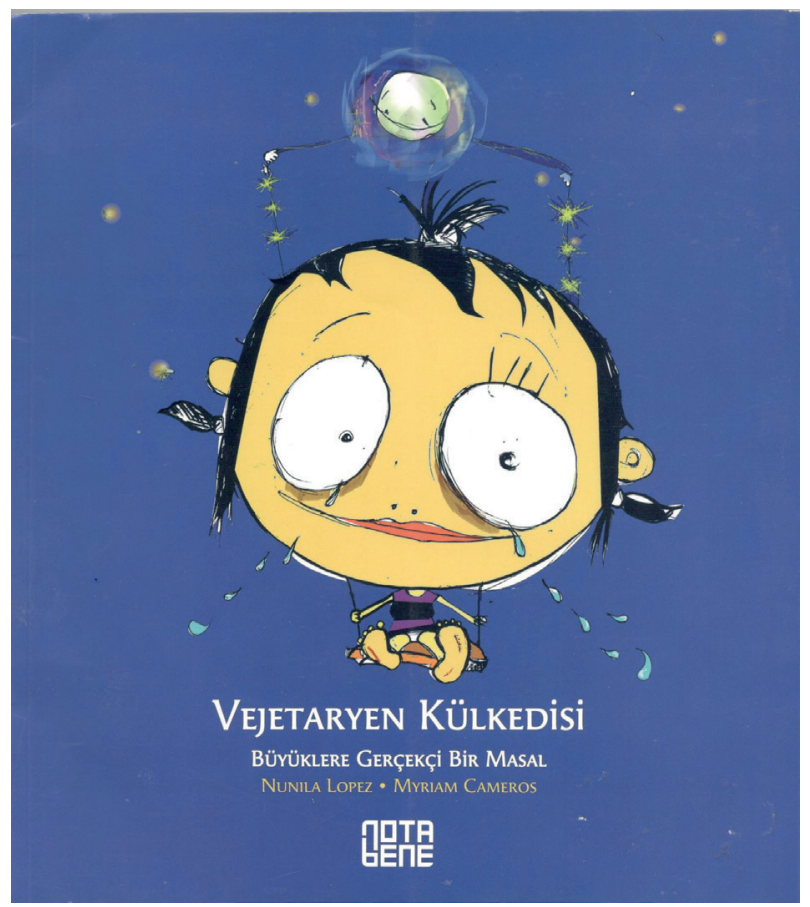

Resim 2: Vejetaryen Külkedisi

Kitap başlığının altında daha küçük punto kullanılarak beyaz renkle ve büyük harflerle yazılan Büyüklere Gerçekçi Bir Masal ibaresi, çocuk okur-yetişkin okur meselesini gündeme getirmektedir. Metin ve diğer metinler arasındaki karşılıklı ilişkilerden anlam çıkarılması demek olan metinlerarasılık, okurun çocuk veya yetişkin olması durumlarında farklı biçimlerde işlemektedir. Christine Wilkie'ye göre çocuk edebiyatında yazar-okur ekseninde dengesiz bir güç ilişkisi vardır. Bu dengesiz güç ilişkisinden dolayı çocuk edebiyatında metinlerarasılığın kendine özgü nitelikleri bulunmaktadır. Yetişkin edebiyatı, yetişkinlerin birbirine yazdığı bir edebî türken çocuk edebiyatında metnin ileticisi ekseriyetle bir yetişkin, alıcısı ise çocuk okurdur. Dolayısıyla çocuklar, yetişkinlerin ilettiği mesajların yetersiz/güçsüz alıııları haline gelmekte, çocuk edebiyatı yetişkin edebiyatının bir alt türü olarak metinlerarası bağlamda işlevselleşmektedir. Çocukların özneler arası bilgisinin saptanması zor olduğu için yazar-okur ilişkisi de asimetrik bir boyuta geçmektedir (Wilkie, 1999, s. 131). 
Öncel metne göndermede bulunan Külprensi ve Vejetaryen Külkedisi, hem daha önce okunan metne hem de şimdiki metne/metinlere karşı bir farkındalık yaratırken okurun öncel metne ilişkin bilgisi kritik öneme sahiptir. Yazar ve okur ortak bir söylem alanı paylaşmadığı takdirde süreç farklı işlemektedir:

Diğer bütün edebi kuramlarda olduğu gibi metinler arasılık kuramında da yazar ve okur metnin alımlama sürecinde ortak bir söylem alanı paylaşırlar. Metinde yer alan olguların, imgelerin, nesnelerin, karakterlerin ve olayların betimlenmesi sonucunda okurun bu betimlemeleri algılaması ve kendi süzgecinden geçirerek bunları tekrar yapılandırması paylaşılan söylem alanının en önemli göstergesidir. Okurun metni alımlaması onun, okuma geleneğine, tür bilgisine ve daha önce edindiği deneyim ve bilgilere bağlıdır. Bu nedenle metinler arasılık kuramında okurun edindiği birikim ortaya çıkar. Okurdan beklenen, metinde yer alan gerek olay örgüsü, gerek ana fikir, gerek edebi tür ile ilgili olarak benzer ya da ilgili öncel metinler ile çağrışım yapmasıdır. Böylece okurun biçemsel, semantik ve linguistik yeterliliği ve bilgisi ön plana çıkar. Okurun anlam üretmesi veya çıkarması ve öncel metinle ilişki kurması okuduğu metne anlam vermesinde de önemli bir rol oynar. Aslında hiçbir metin, diğer metinlerden, kendi gelenek ve türlerinden ayrı şekilde var olamaz. Bir metnin varlığı ancak diğer metinler içinde anlam kazanmasına bağlıdır. Bir metni metin yapan veya onu özel kılan şey, gerçekte diğer metinlerle olan ilişkisidir. Bu durumda bütün metinlerin metinler arası bir özellik barındırdığı sonucuna varmak mümkündür. (Tüfekçi Can, 2014, s. 263-264)

Çocuk okur; okumaya başlamadan önce çizgi film, animasyon, resim gibi metinlerarası özellik gösteren görsel kurgular aracılığıyla metinlerarası ilişkilere karşı deneyim geliştirir. Hatta çocuklar ilk karşılaştıkları görseli doğru değer şeklinde algıladıktan sonra farklı bir söylem üreten metni gerçek kabul etmeyebilir (Wilkie, 1999, s. 133). Başka bir deyişle çocuk okur, metinlerarası ilişkilerle yazılı metinlerden önce farklı bağlamlarda karşılaşarak ürettiği bakış açısı ve algılama biçimlerini gerçek olarak kodlayıp sonrasında karşılaştığı özgün metinleri yadırgayabilir veya söz konusu metinlere karşı inançsızlık duygusu geliştirebilir. Bununla beraber yaş itibariyle çocuk okurun belli bir bilgi birikimi, okuma kültürü veya öncel metinlerde geçen birtakım söylemsel ifadelere rastlamış olabileceğine ilişkin bir varsayım üretmek gerçekçi bir yaklaşım değildir (Tüfekçi Can, 2014, s. 266). Bahsi geçen farkındalığa sahip olan Lopez ve Cameros Büyüklere Gerçekçi Bir Masal 
ifadesiyle anıştıılan ve uyarlanan öncel metin odağında yaratılan ironik kurguyu okur bağlamında garantiye almaktadır. Çocuk okur ise eserde metin ve görsel unsurlarla yaratılan ironiyi anlamasa da klasik masal kurgusundan ayrılan bir yapıya karşı bilinç geliştirmektedir. Diğer bir ifadeyle bu yetişkinler için bir masal olsa dahi gerçeği bilmek isteyen yüksek farkındalık sahibi çocuklar, Külkedisi masalının klasik ve özgün tasarımlarına karşı kendilerine özgü deneyimler geliştirebilecektir.

Vejetaryen Külkedisi'nin kapağında koyu mavi arka plan önünde merkezde konumlanan ve salıncakta sallanan iki boyutlu kadın figürü, eş zamanlı olarak hem ağlamakta hem de gülmektedir. Başında bir insanın kendini kurtarabilecek tek kişinin kendisi olduğunu simgeleyen ve bireyin aydınlanmasına işaret eden haleli ay benzeri bir sembol bulunan ve hem salıncakta oturma şekli hem de perspektiften dolayı iç çamaşırı görünen figür, vücuduna göre oldukça büyük çizilmiş başıyla orantısız bir anatomik yapıya sahiptir. Klasik Külkedisi'ne benzemeyen estetik karakterin feminist kültürle birleşmesini temsil eden betimleme, yüksek ve düşük sanatlar arasındaki çizgiyi bulanıklaştırmaktadır.

Anlatıının tonlamalarına ve vurgulara göre farklı yazı tipi, punto ve renklerde yazılan, yer yer parantez içine alınan minimalist metinler ile çerçevesiz görsellerden oluşan resimli kitapta, kadının konumu odağında toplumsal eleştiri yapılmakta, Külkedisi'nin özerk ve farkıı bir versiyonu yeniden yazılmaktadır. Resimlerde dış ya da iç çerçevenin kullanılmaması, hikâyenin tam bir yaşamsal deneyimi yansıttığı, imgelerin sonsuz ve özgür olduğu manalarına gelmektedir (Moebius, 1988). Eserde anlatılan hikâyenin özü, orijinal Külkedisi masalının ikiliklere dayanan kurgusunu ve cinsiyetlere vadettiği sınırlı dünyayı sona erdirmeye dayanmaktadır. Keklik yemek istemeyen başkahramanıyla Vejetaryen Külkedisi, her türlü istismara karşı savaşmayı teşvik eden ve öz sevginin en önemli şey olduğunu vurgulayan modern ve gerçekçi bir masaldır. Bir gün hayatlarının inandıkları/inandırıldıkları masal olmadığını keşfeden kadınlar, çocuklar ve bütün okurlar; bu kitapla beraber klasik Külkedisi hikâyesini vejetaryen ve aynı zamanda asi bir kahramanla yeniden keşfetme imkânı bulmaktadır. Kadınlara fısıldanan cinsiyetçi mutluluk tablosunu klasik bir masal ile sorgulayan kitap; dayatılan güzellik algısı uğruna kadının ayağını sıkan ayakkabılara, bedenini saran elbiselere mecbur olmadığını vurgulayarak okuru Yeter Perisi (Hada Basta) ile tanıştırmaktadır. Böylelikle edilgen kılınan kadınların söylemeyi unuttuğu sihirli kelime olan yeteri kullanan Külkedisi; vejetaryen ve feminist kimliğiyle öne çıkar. Bununla beraber yazar ile çizerin Barselona'daki karşılaşma hikâyeleri ve kitabı yazma serüvenleriyle masal devam eder. 


\section{Metamorfoz: Eski Bir Masal için Yeni Perspektifler}

Cinsiyet ve cinsel kimlik rolleri hakkındaki normatif kurguları istikrarsızlaştırmaya çalışan, cinsiyet ve cinselliğin değişen, istikrarsız ve nihayetinde bilinemez temsilini savunan iki eserde, baskın cinsiyetçi ideolojileri aktarmaya meyilli olan Külkedisi masalııın kalıpları bir direniş unsuruna dönüşmektedir. Anlatılar boyunca öncel metnin kodları öylesine belirgindir ki; okurdan beklenen bunları tahmin etmesi ve yerlerini saptamasıdır. Orijinal masalın, şeyleri ve ilişkileri temsil etme biçimlerine ilişkin geçmişten bugüne süregelen şema ve senaryoları ironik şekilde dönüştüren yazarlar, değişen dünya düzeniyle beraber cinsiyetin nasıl gerçekleştirildiği ve cinsiyete hangi kriterler eşliğinde değer verildiği konularına anarşik, absürt, oyunbaz ve gülünç tavırlarla yaklaşır. Öncel metinde erkeklerin otoriter, aktif, kurtarıcı ve fiziksel bakımdan güçlü; kadınların ise pasif, domestik, olumsuz ve sıradan özelliklerle kurgulanmasının aksine incelenen yeniden yazımlarda, çocuklara yeni bir ideal kadın imajı sağlamak için kadın karakterler daha cesur, aktif ve bağımsız tasvir edilmektedir. Dolayısıyla cinsiyet temsilleri, karakterler için mevcut olan özne konumlarının daha karmaşık tasvirlerine izin vermektedir.

Külprensi; ötekileştirilen, alay konusu edilen ve gülünç olan erkek figürlerle başlayıp bitmektedir. Anlatıda zorba kardeşlerine boyun eğen Külprensi ile onu bu hayattan kurtaran Prenses Şekerkuruş (Princess Lovelypenny) eşliğinde hem kadınsı hem de erkeksi hegemonik normlar ile Kaslı Adam Dergisi, "Iri adam kremi kullan!", Işıltılı Temizlik (2016) gibi görsel ve metinsel ipuçlarıyla kapitalist toplum yapısı ve ataerkil odaklı beğeni anlayışı eleştirilmektedir. Cinsiyetleri belli kalıplara sokmayı ve tek tip modeller yaratmayı hedefleyen beğeni/güzellik anlayışı, masallarda özellikle büyü yoluyla elde edilir (Agvan ve Asutay, 2018, s. 230). İncelenen metinde ise perinin büyüleri yanlış yönde işleyerek toplumun idealize ettiği güzellik imgesine ulaşılamaz ve Külprensi, bahsi geçen imgenin parodik hâli olan mayo giyen büyük ve kıllı bir maymuna dönüşür. Biraz temizlendikten sonra güzelleşen ve büyüyle prensese dönüştürülen Külkedisi'nin aksine bu masaldaki başkahraman; baloya gitmesi için yapılan büyünün etkisiyle diğerlerinin korkacağı bir maymun haline gelir:

"Gözü kertenkelenin, ayak parmağı sıçanın, dönüşsün takım elbiseye şu paçavraların!"Peri, “Hay aksi" diye söylendi." Yüzücü kıyafeti demedim ki!” "En büyük dileğini yerine getireceğim; hem iri yarı hem de kıllı OLACAKSIN." Külprensi gerçekten de iri yarı ve kıllı olmuştu! "Ah şu sıçanlar!" dedi peri, "Yine bir işi beceremediler, neyse ki gece yarısı büyünün etkisi geçiyor." 
Külprensi, büyük ve kıllı bir maymuna dönüştüğünden habersizdi; bu da böyle bir büyüydü işte. (2016)

Külprensi, büyünün haricinde kıyafet tarzı ve fiziksel görünüm bakımından metnin başında ve sonunda değişmemesine rağmen prensesle evlenmekte, yaptığı evlilik sayesinde yaşam standardını yükseltmekte ve eski kot pantolonu ile gömleğinin yerini aynı modellerin yenileri almaktadır. Eski hâline kıyasla görülen farklıık ise beyaz önlüğün yerine boynunda renkli bir kravatın bulunmasıdır; çünkü Külprensi, prenses sayesinde sınıf atlamıştır. Bununla beraber orijinal masaldaki ayakkabının/terliğin yerini toplumsal konum ile cinsiyetin belirgin göstergelerinden biri olan ve cinsel bölgeyi de kapsayan pantolonun alması, insanlar arasında statü belirleyici bir unsur olarak giysi formlarına dikkat çekmektedir.

Külprensi, orijinal masalla kıyaslandığında klasik yapı tersine çevrilmiş gibi görünse de iki masalın temel dayanakları ile eylem motifleri neredeyse aynı işleve hizmet etmektedir. Masalın şematik kurgusunda kadın karakterler olay örgüsünün sonunda prensese dönüşürken bu masalda erkek prense dönüştürülmekte, benzer yapı farklı cinsiyet odağında üretilmekte ve prens-prenses hayatı öncel metinde olduğu gibi idealize edilmektedir. Külkedisi erkek olsa dahi erkeğin başına gelenler diğer masallardaki muadillerinden farklı değildir. $\mathrm{O}$ da kardeşlerinin zorbalığına maruz kalır, mücadele etme yeteneğinden yoksundur, dışardan bir gücün yardımına ihtiyaç duyar, evleneceği kişiyi seçmekten acizdir, düşürdüğü bir eşyası aracılığıyla kendisi seçilir ve kendisine sunulan hayatı yaşamaya devam eder. Zulmüne uğradığı kardeşlerinden intikam alan fail bile Külprensi değil, onunla evlenen Prenses Şekerkuruş olmaktadır: "Ve prenses Şekerkuruş, periden, Külprensi'nin iri yarı, kıllı ağabeyleriyle ilgili bir dileği yerine getirmesini istedi... Peri, onları ev perilerine dönüştürdü; etrafı sile süpüre sarayın bir ucundan öbür ucuna sonsuza dek koşturup durdular." (2016). Zenginliğine rağmen Şekerkuruş'un gece yarısı, yalnız başına otobüs beklemesiyle okurun klişe algılarına alternatifler üretilmekte, alaylı ve çoklu imleyenlerle beraber zıtılıklar teşhir edilerek sınır meselesi sorunsallaştırılmaktadır. Incelenen masalda zenginlik sahibi olan, arayıp bulan ve erkeğe statü atlatan kadındır: "Prenses parmağıyla Külprensi'ni işaret ederek; 'Bir de o denesin bakalım' dedi. Ağabeyleri, alaylı alaylı gülerek'Bu pantolon hiç o bücüre olur mu?' dediler. Ama pantolon oldu! Prenses Şekerkuruş hiç beklemeden Külprensi'ne evlenme teklif etti." (2016). Yine durak sahnesinde Şekerkuruş'un Külprensi'nin kendini kurtardığını sanmasıyla yanlış anlaşılma aracılığıyla masalın erkek kurtarııı temsiline gönderme yapılmakta ve bu temsil eleştiriye açılmaktadır. 

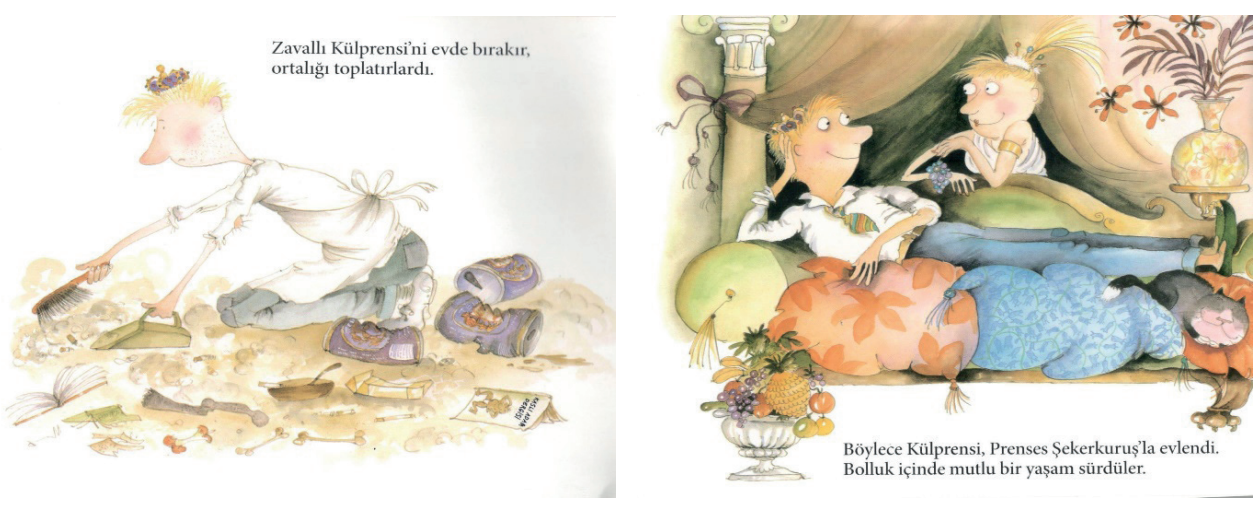

Anlatıda orijinal masalın rol dağılımının kadın-erkek odağında değiştirilmesi, ejderhaların evcil köpek pozisyonunda kurguya dâhil edilmesi, evdeki pislikte bolca izmaritin bulunması, bütün karakterlerin başındaki kraliyet tacıyla prens ve prenseslerin çoğaltılarak sıradanlaştıııması gibi klasik anlatı yapısına ters düşen özellikler olmasına rağmen normatif klişeler sürdürülmektedir. Zira mesele, kadın ve erkeğin yer değiştirmesi şeklinde ikili karşıtlığa dayandırılan bir dönüşümle açıklanmayacak kadar derindir ve cinsiyetler arasında dikotomik bir kurgu yaratarak bireyin biricikliğini vurgulamadan eşitsizliği ortadan kaldırmak mümkün değildir. Dolayısıyla zıtıkların yer değiştirmesi, benzer yapının farklı bir kurguyla yeniden üretilmesi anlamına gelmektedir. Bununla birlikte prens ve prensesin sarışın betimlenmesi, Külprensi'nin edilgenliğinin öne çıkarılması, perinin büyülerinin belirleyici olması, evlilikle beraber toplumsal statünün iyi yönde değişmesi, iyilerin kazanıp kötülerin cezalandırılması, başkahramanın hak ettiği lüks yaşama kavuşması, sonsuza dek vurgusunun yapılması gibi klasik kalıplar sürdürülmektedir.

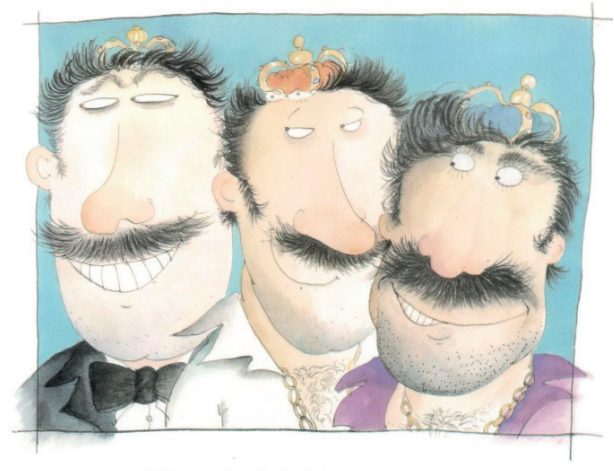

Külprensỉnin bu haliyle hiç durmadan dalga geçen üç kıllı ağabeyi vardı.

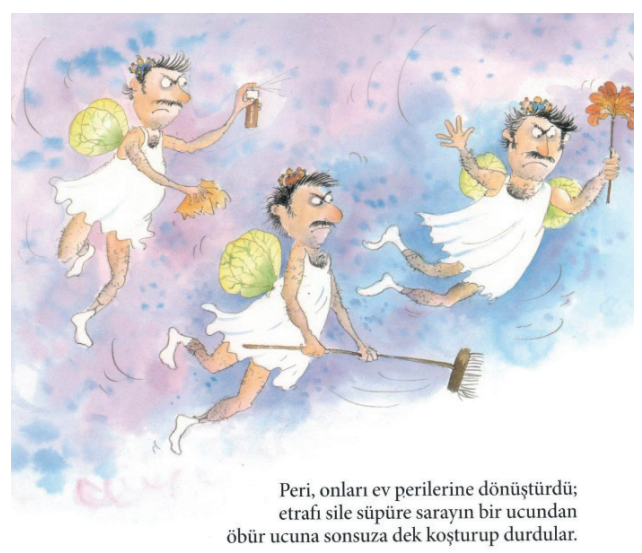

Litera Volume: 31, Number: 2, 2021 
Prenses arkadaşlarıyla Saray Diskosu'na giden ve kendilerine benzemeyen sıska kardeşlerini temizlik yapması için evde bırakan üç büyük kıllı erkek kardeş figürü maskülen kalıpları simgelemektedir. Hem görsel hem de eylem bakımından ataerkil ideolojide erkeğe ait kılınan erkeksi nitelikleri imleyen egemen erkekliğin mükemmel örnekleri ile peri tarafından cezalandırıldıktan sonraki pembe ağırlıklı arka plandaki beyaz elbise giymiş ev perisi hâlleri arasındaki durumu normatif düzlemde ele almak mümkündür. Hikâyenin sonunda kardeşlerin dönüşümü, hem perinin önceki başarısız büyülerinin kasıtlı yapılma ihtimalini gündeme getirmekte hem de son cezalandırıcı hamleyle beraber heteronormatif kodlar yeniden üretilmeyerek erkek eşcinselliği imlenmektedir. Bununla beraber peri; heteroseksüel, hiper maskülen erkekleri eşcinselliğin göstergelerine dönüştürme kararında onları melez bırakır; fiziksel özelliklerini ve tutumlarını koruyan kardeşlerin kıyafetleri, toplumsal konumları ve duruşları değişir. Dolayısıyla masalın sonunda eşcinsellik ile silme süpürme gibi ev işleri bir cezalandırma biçimi olarak ortaya çıkmaktadır (Orme, 2016, s. 230).

Anlatının sonundaki büyü yıkıcı ve çözülemezdir. Nihai kapanışın bir perinin yardımıyla lüks içinde yaşama ve intikama bağlı bir şekilde bitirilmesi, postfeminist bakış açısına göre onaylanacak bir durum değildir. Eser, cinsiyet hiyerarşisini tersine çevirir; ancak söz konusu değişimde ikili zıtlıklar yok edilmez, aksine birbiriyle yer değiştirir. Nihayetinde normatif cinsiyet temsilleri ile heteronormatiflik yeniden pekiştirilir ve kapitalist sistem eleştirilirken özellikle idealize edilen mutlu sonla beraber tekrar inşa edilir. Aynı zamanda cinsiyet ve cinsellik hususlarında özerkliği anlamayı ve desteklemeyi reddederek homofobik kalıpları sürdüren peri aracılığıyla masallar ve çocuk edebiyatı hakkındaki bütünleştirici dürtüleri ve ütopik varsayımları rahatsız eden; ama asimile edemeyen bir alan yaratıır. Diğer ifadeyle Külprensi'nde masalın cinsiyetçi normları eleştirilse dahi yazar sığ bir boyutta cinsiyet rollerini değiştirmekle sınırlı kalarak cinsiyetçi rolleri yeniden üretmekten kurtulamamaktadır.

Vejetaryen Külkedisi, geleneksel hikâyelerin nesillere aktardığı değerleri reddeden cesur kadınlar için yazılan bir masal olduğu vurgusuyla sunulur. Bu alternatif masalın yazar ve çizeri; cesur prenslerin olmadığı ve mutlu sondan sonra kekliklerin yenmediği bir hikâyede okuru partileyen asi bir vejetaryen Külkedisi'yle tanıştırır. Özü geleneksel bir masalı üstlenme ve dönüştürme olan eserin meselesi, güzel ve edilgen bir Külkedisi sunmak değil; ataerkil toplumda birçok kadının uğradığı fiziksel ve psikolojik tacizi göstermek hakkındadır. Orijinal hikâyenin büyüleyici prensi, kadının sömürmeye odaklı patronu veya evliliğindeki mutluluğunu umursamayan anlaşılmaz kocası olabilir. Eleştirel 
yeniden yazım, okuru ev içi alandaki istismar gibi bazı toplumsal baskıların kökenini düşünmeye davet etmektedir. Çoğu durumda, ergenlik döneminde sahiplenici bir aşk hikâyesi olarak başlayan şey, cinsiyetçi trajedi ile bitebilir ve bu rahatsız edici gerçeği, çocuklara ve dolayısıyla ebeveynlere seslenen masallarla aktarmak ve bireyleri uyarmak hayati öneme sahiptir.

Vejetaryen Külkedisi'nde orijinal masalın karakter kurgusu ile eylem motifleri kullanılır. Külkedisi'ne kötü davranan üvey anne, kız kardeş ve baba figürleri, baloya gitme arzusu, cam ayakkabı meselesi, prensle evlenme ve perinin yardımı; bu masalda da bulunmaktadır. Ancak özellikle Külkedisi ve prens olmak üzere karakter ve eylemlere yüklenen değerler parodik ve ironik anlatı stratejileriyle dönüştürülerek cinsiyetçi bakış açılarına karşı alternatif duruşlar sergilenmekte ve masalın temel dinamiği feminist bir başkalaşım geçirmektedir.

Vejetaryen Külkedisi, Külprensi'yle kıyaslandığında kendi kararlarını alan bir karakter olarak okurun karşısına çıkar. Onun yanılgısı, ailesi ve çevresi tarafından kendisine dayatılan rollerdir. Bir apartmanda yaşayan mor mini elbiseli, dişleri ayrık ve kocaman gözlü Külkedisi'nin baloya gitmek istediği ve istediğini elde ettiği sahnenin anlatıldığı resimde o, balkondan sarkar bir hâlde gökyüzündeki aya bakmakta ve gülümsemektedir. Kitabın kapağında karakterin başında bulunan ve kollarıyla onu sarmalayıp üstten aşağıya doğru yıldızlar döken ay; kişinin bilincinin, dolayısıyla bir insanın hayatına dair kararları sadece kendinin verebileceğinin sembolüdür. Baloya giden, ölçüyü kaçırıp sarhoş olan Külkedisi; geceye dair hiçbir şey hatırlamaz ve kendine geldiğinde ellerinde burnundan topuğuna kadar cam ayakkabılar tutan iki beyefendiyle karşılaşır. Külkedisi, başta dar gelen ayakkabıları zorlaya zorlaya ayağına geçirir; çünkü prens ile evlenmek zorundadır. Bu mecburiyet, kendi isteği dışında toplumun dayatmalarıyla şekillenmektedir. Böylelikle orijinal masalın değişmeyen klişe kalıbına gönderme yapılarak kadınların istemedikleri yazgılara mecbur kılınması eleştirilmektedir:

Külkedisi baloya gitmeyi çok istiyordu... sonunda istediğini elde etti. Fakat baloda ölçüyü öyle kaçırdı ki, ertesi gün hiçbir şey hatırlamıyordu. saat 12 'de eve döndü ama ertesi gün öğlen 12'de DiKKAT! Bu durum baygınlığa yol açacak kadar tehlikeliydi. Yaşadığı karmaşaya rağmen yine de iki beyefendi tam karşısında duruyor, ellerinde tuttukları burnundan topuğuna kadar cam ayakkabıları... Külkedisi'nin denemesi için bekliyorlardı. Başta ayakkabılar dar geliyordu ama zorlaya zorlaya ayağına geçirdi... çünkü prens ile evlenmek zorundaydı. (2017) 
Külkedisi'nin prens ile hayatının anlatıldığı metinler ile betimlendiği görseller, klasik masalın idealize edilen görünümüyle uyuşmamaktadır. Evlilik fotoğrafının yer aldığı çerçevenin sağ üst köşesinde biri büyük biri küçük olmak üzere iki altın alyans, sağ alt köşesinde ise yine biri büyük biri küçük olmak üzere öpüşen iki beyaz kuş vardır. Kadın ve erkeğin medeni durumunun önde gelen göstergeleri arasındaki alyans, tüketim kalıpları içerisinde simgeleştirilmiş bir üründür. Bu simgeye gönderme yapan çerçevenin içindeki fotoğrafta Külkedisi ile prens arasındaki etkileşim sevişen kuşlarınkine benzememektedir. Topuklu cam ayakkabılarını giyen ve elinde iki dal çiçek tutan Külkedisi; şaşkın, mutsuz ve tedirgin bir şekilde aşağıdan yukarıya doğru prense bakmaktadır. Ona üstten bakan prens siyah, gri, beyaz renklerle kombinlenen bir takım elbise giymektedir. Başında kraliyet tacı bulunan prensin yüzünde sadece kaşı ve ağzı simgeleyen iki çizgi vardır. Bahsi geçen çizim tarzının sebebi; ilişkileri boyunca prensin devamlı karısına kızması, bağırması ve yemek için keklik istediğini emretmesidir. Vejetaryen Külkedisi, et ve balık yemediği, deri ceket dahi giymediği hâlde kocasına her gün keklik pişirmek zorundadır; çünkü prensin en sevdiği yemek kekliktir. Buna rağmen huysuz prens “Bu yemek yanmış!", "Çok tuzlu olmuş!", “Bu yemek çiğ kalmış!" (2017) diyerek sürekli bağırıp çağırmaktadır. Bağırdığı görselde kanepeye oturan, ellerini yumruk yapan ve yemek tabağını tekmeleyen kaşları çatık prensin üzerinde beyaz atleti ile alt pijaması vardır. Atletinden fırlayan kıllı göbeği ile vücudu maskülenliği, başındaki tacı ile taht benzeri koltuğu ise kadın üzerindeki egemenliğini vurgulamaktadır.

Külkedisi'nin, erkeğin egemenliğini destekleyen ev içi görevlerini yerine getirirken topuklu cam ayakkabıları giyme zorunluluğunun olması, ayaklarını yara bere içinde bırakır. Ancak yara bere içinde kalan sadece ayakları değildir; çünkü metne göre ayak tabanı tüm organların aynasıdır. "Köreltilmiş rahim, ezilmiş göğüs, kırılmış kalp." (2017); erkek egemenliğinin ve dayatmacı bir toplumun kadında bıraktığı hasarlardır. Sadece kadında bulunan rahim ve erkeğinkinden farklı anatomik özellikler gösteren göğüs aracılığıyla erkeğin kadın bedenindeki sömürüsüne gönderme yapılmaktadır. Erkeğin hizmetçisi, arzu nesnesi, cinsel objesi şeklinde farklı ve edilgen kimliklerde konumlandırılan kadın; hasta, bunalımlı ve şaşkındır. O uyurken üzgün bir yüz ifadesiyle onu uzaktan takip eden ay metaforu, kadının bilincinin henüz uyanmadığı anlamına gelmektedir. 

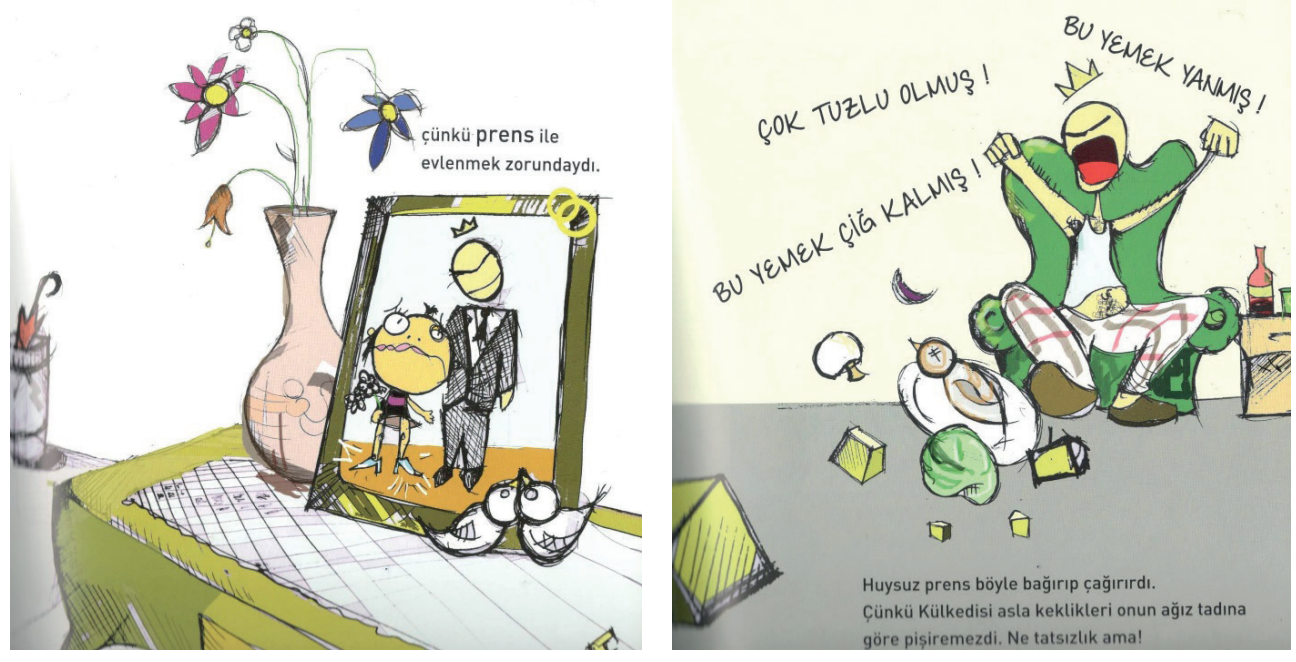

Yaşadığı hayatı zamanla sorgulamaya başlayan Külkedisi; prens, ayakkabılar ve kekliklerle ilgili düşüncelerini çevresindekilere anlatmaya karar verir:"Külkedisi gittikçe daha kötü hissediyordu. HASTA... BUNALIMLI... ŞAŞKIN... Bir gün anlatmaya karar verdi: Bıktım artık prensten de ayakkabılardan da kekliklerden de" (2017). Modern arkadaşı şikâyet etmemesini, kendisinin de kocası istediği için yarım metrelik platform ayakkabılar giydiğini söyler. Aynı tepkiyi veren mahalledeki arkadaşı ise kocasının dana eti yediğini ve bütün gününü mutfakta fııın başında geçirmek zorunda olduğunu ifade eder. Diğer kadınlarla benzer bir tutum sergileyen ana kraliçe, sinirli bir şekilde şikâyet etmemesini emreder; çünkü ona göre hiçbir yer bir prensin yanından daha iyi değildir. Yalnızca dogmatik olmayan köpekli arkadaş "Ama sen vejetaryen değil miydin? Hem yalınayak yürümek hoşuna gitmez miydi senin?" (2017) diyerek Külkedisi'nin durumuna üzülür.

Ataerkil bilinçdışının oluşumu ile insan belleğine yansımasında kadının işlevi iki boyutla sınırlandırılmaktadır. Penisten yoksun kadın iğdiş edilme endişesini simgelemekte ve çocuğunu bu simgesel düzende yetiştirmektedir. Çocuğun ardından ise kadının toplumsal yapıdaki anlamı son bulmaktadır (Mulvey, 2014, s. 28). Böylece simgeseli aşamayıp semiyotiğe ulaşamayan, kutsal anneliği içselleştiren ve kız çocuklarını kutsallığın aktarıcısı olarak yetiştiren kadınların tutumlarının nedeni, hemcinsine zarar veren toplumsal geleneklere bağlı kalmalarıdır. Dogmatik olmayan köpekli arkadaş dışındaki kadınların ataerkil düzene sağladıkları uyum, anneler ile diğer kadınların toplumun 
kendilerine biçtiği rolleri içselleştirdiğini ve eril gardiyanlara dönüştüğünü sembolize etmektedir. Yoğun annelik ideolojisinin onlara dayattığı tekil mevcudiyet modelinde ısrarcı olan kadınlar, hegemonyanın sürdürülmesini sağlayan dinamik katılımcılardır. Bu sebeple Külkedisi'nin platform ayakkabı giyen ve dana eti pişiren arkadaşları, hoşlanmadıkları hâlde eşlerinin isteklerini yerine getirirler ve arkadaşlarına da kadının baskılanmasını sürdüren yönde telkinde bulunurlar.

Metin içinde hangi yiyeceklerin seçileceğini belirleyen hümanist ve ataerkil ideolojilere özgü değerler; insanların gıda seçimleriyle ilgili duyguları, stratejileri ve eylemlerinin başlıktaki vurgusunu desteklemektedir. Kadının yemek hazırlığı için alışveriş yapması, diğer kadınlarla beraber kasap kuyruğunda beklemesi, sürekli etli yemek pişirmek zorunda olması, ölü kekliği ağlayarak tencereye atması, prensin sağlıksız görüntüsü anlatı boyunca keklik özelinde et yemenin olumsuzluğunu vurgulamakta ve kadının baskılanması bu metaforlar aracılığıyla anlatılmaktadır. Bir gün kasap sırasında aynı amaçla bekleyen birbirinden farklı kadınları seyreden Külkedisi, kendini görme şansını elde eder. Kasabın elindeki baltaya yansıyan yüzü, ona inandığı tüm değerleri sorgulatır ve kendini kurtarabilecek tek kişinin kendisi olduğunu anlar:

Ve bir prensin onu kurtaracağına inanacak kadar saf olduğu için kendine gülmeye başladı. Yıllarca birlikte yaşadıktan sonra, prenslerin seni kurtarmayacağını anlarsın. Ne kamyon şoförleri, ne şarkıcılar, ne de bakkallar... Suçluluk duymayı bıraktı ve kendini affetti. Anladı ki, seni kurtarabilecek tek kişi... SEN KENDINSIN! Böylece Külkedisi“'YETER!" dedi ve birden "Yeter Perisi" beliriverdi. (Şunu hemen belirteyim, periler tombul, kıllı ve esmer olurlar, hepimizin içinde yaşarlar ve "yeter!" dediğimizde ortaya çıkarlar). (2017)

Görüldüğü üzere öncel masalda kullanılan büyü yapan ve yardım eden peri motifi tam anlamıyla yapıbozuma uğratılır. Bu masalda peri, kişinin kendisidir ve kişiye ancak kendi kararlıı̆̆ı yardım edebilir. Kendini keşfeden Külkedisi, "ilk olarak prens için ağladı, onca ölü keklik ve cam ayakkabılar için. Sonra ona kötü davranan üvey annesi ve ondan da kötü davranan babası ve kendisini 34 beden elbise giymeye zorlayarak ölecek hale getiren kız kardeşleri için ağlamaya devam etti." (2017). Bahsi geçen ağlama sahnesi, öncel masalın karakter kurgusunu anıştırıp babayı masum kılan söylemi eleştiriye açmaktadır. Masal boyunca Külkedisi'ne yapılan kötülüklerin anlatının kadın karakterleri tarafından gerçekleştirildiği iddia edilerek baba, kızının yaşadıklarından muaf 
tutulmaktadır. Ancak Vejetaryen Külkedisi'nde babanın üvey anneden daha kötü davrandığı vurgulanır ve kötülük ile kadın eşleştirilmesi sorunsallaştıııır.

Ağlayıp içini boşaltan karakter, boyun eğen edilgen kimliğinden sıyrılarak önce prensi terk eder ve keklikleri bırakır. Ardından güzellik algısı aracılığıyla dayatılan ve ayağını acıtan topuklu ayakkabılar ile vücudunu sıkan 34 beden kıyafetleri çıkararak çıplaklığıyla beraber ihmal ettiği bedenini keşfeder. Böylelikle toplumun varoluşuna yüklediği ağırlıklar olmadan kendini ifade eder ve kendi bedenine sahip çıkar. Ruhunu ve bedenini özgür kılmak için dans ederken kalıpların ve insanları sınıflandıran vasıfların önemsiz olduğunu daha iyi anlar: "Ne 42 numara ayakkabı giymek önemliydi, ne 90 kilo olmak, ne 1,92 boyunda olmak ne de 80 yaşında olmak..." (2017). Kendisine güvenmeyi ve vakit ayırmayı öğrenen Külkedisi; bir yanında fatura, diğer yanında anarşist, feminist ve çevreci yazar Ursula Le Guin'in kitabı ile elinde tuttuğu Utanç Bitti adlı kitapla huzurlu bir şekilde uyurken resmedilmektedir. Bu görsel, karakterin hem haz alma ve karar verme yeteneklerini geliştirdiği hem de maddi anlamda kendi ayakları üzerinde durduğunu vurgulamakta ve okura otoriteyi reddeden, kendini aramaya başlayan bir kadın modeli sunmaktadır. Sadece teoriyle kendini kısıtlamayan Külkedisi; hayata karışıp onu deneyimleyerek, kendisi gibi olan başkalarıyla karşılaşarak öğrenmeye ve gelişmeye devam eder:

Kilo almaya başlayan ve şimdi daha çok çıkma teklifi alan Süslü Fare ile, Uyanmakta (Prozak'tan temizlenme aşamasında) olan Uyuyan Güzel ve Pamuk Prenses ile,

Avcının saldırgan davranışlarına maruz kalmış olan Kırmızı Başlıkı Kız ile, (Duygusal körlük yüzünden avcının tüfeğini görememişti.)

Kendi yalanlarından bıkmış ve gerçeğe ihtiyacının farkına varmış Pinokyo ile, Ve ağlaya ağlaya kalbini bulan Teneke Adam ile. (2017)

Karşılaştığı kadın ve erkek karakter örnekleri, yapıbozumun Külkedisi masalı ile sınırlı kalmadığına işaret etmektedir. Söz konusu karakterlerin yer aldığı masallarla ilgili detay verilmese de çocuk edebiyatında öne çıkan cinsiyetçi masalların birkaçına değinilerek bu anlatıların da değişime ihtiyacı olduğu ima edilir. Külkedisi'nin "Ahenk ile Dolup Taşıyorum" adlı içerisinde dans edilen bir vejetaryen restoran açtığının belirtildiği ve maddi bağımsızıı̆ını kazandığının mesajının verildiği bölümde, bahsi geçen karakterler ile ana kraliçe ve dogmatik olmayan köpekli arkadaşın son durumları hakkında bilgi verilerek cinsiyet ayrımı yapılmadan bütün bireylerin kendi hayatlarında etkin olduğu/ 
olması gerektiği vurgusu yapılır. Özellikle evlilik teklifi beklerken hayatları mahvolan edilgen kadınlar başta olmak üzere bu karakterlerin hepsi yüzyıllar boyunca masallarda temsil etmek zorunda kaldıkları rollerin farkına varıp artık kendi masallarını kendileri yazmaktadır.

Külprensi'nde öncel metne uygun olarak sonsuza dek vaat edilen mutlu sona Vejetaryen Külkedisi'nde rastlanmamaktadır. "Bitti." yazdıktan sonra " Tamam, tamam. Bitti diyoruz ama sonların olmadığını biliyoruz. Her şey devam ediyor." ifadeleri anarşist tavrın kapanışta da sürdürüldüğünü göstermektedir. Devamında yazar ile çizerin tanışması ile işbirliğinin anlatıldığı "Bir Hikâyenin Öyküsü ya da Bir Buluşmanın Hikâyesi” başlı̆̆ı altında üstkurmaca özellikleri sergileyen metin, okuyucuya kurmaca bir eserle karşı karşıya olduğunu hatırlatmakta ve kendi kurgusallığını öne çıkarmaktadır. Böylelikle metnin kurgusallı̆̆ına dikkat çekilerek gerçek ile kurmaca arasındaki ilişki sorgulanmakta/ sorunsallaştırılmakta ve masal yapısıyla beraber tüm kurmaca türleri parodik biçimde sarsılmaktadır.

\section{Tartışma ve Sonuç}

Masalların yeniden yazımları vasıtasıyla cinsiyet eşitliğinin öğretilmesine XX. yüzyılın ikinci yarısı itibariyle kritik bir önem atfedilmesine rağmen bu eserler hakkında kâfi derecede çalışmanın yapılmaması, klasik masallar ile onların modern versiyonlarının incelenmesini gerekli kılmaktadır. Klasik masal konvansiyonlarını cinsiyet eşitliği odağında yeniden yorumlayan eserlere çok kültürlü bir bakış açısıyla eleştirel bir perspektiften bakmak, aktarılmak istenen mesajların görünür kılınmasına yardım eder. Illetilen mesaj bakımından öncel masalla uyum göstermeyen Külprensi ile Vejetaryen Külkedisi, orijinal Külkedisi masalının bazı yönlerden değiştirildiği modern varyasyonlardır. Tek boyutlu çocuk/birey yaratma eğilimini destekleyen Külkedisi masalının yapıbozuma uğratılarak dönüştürülmesi ile benzer hiyerarşik varsayımlar üretilse dahi cinsiyetler arasındaki sınırların geçmişe oranla belirsizleştirilmesinin öncesinde karşılaştırmalı bir şekilde incelenmemiş örneklem dâhilinde ortaya konulması, çocuk edebiyatına odaklanan cinsiyet çalışmalarına katkı sunmaktadır. İncelenen yeniden yazımların iki farklı edebiyattan seçilmesi ise çoğulcu kültürel bir karşılaştırmayı mümkün kılmaktadır.

Çalışmada okul öncesi çocuklara ve büyüklere hitap eden Külprensi ile Vejetaryen Külkedisi adlı resimli kitaplarda karakter ve eylem nitelikleriyle eşleştirilen değerlerin klişe anlatı stratejilerine karşı gelerek alternatif özne pozisyonları yarattığı tespit edilmiştir. 
İki eserde de çocuk edebiyatının temel kuralları yaratıı yenilikçi kullanımlarla beraber kendi dışına açılmakta, cinsiyetlere atfedilen güzel, yakışıklı, zayıf, kaslı ya da genç olma zorunluluğu eleştirilmekte ve prensesin prens tarafından kurtarılması değil, onun biricik varoluşu ön planda tutulmaktadır. Böylelikle incelenen iki metnin, klasik masalın kalıplarıyla dolayısıyla cinsiyetlendirilmiş geleneksel niteliklerle mücadele ettiğini söylemek mümkündür. Bununla beraber Külprensi, öncel metin olan Külkedisi masalını toplumsal cinsiyet kurguları ekseninde dönüştürürken benzer hiyerarşik yapıyı yeniden üretmekten kurtulamamaktadır. Diğer bir ifadeyle Vejetaryen Külkedisi'nin öncel metin bağlamında masal geleneğinden kopuşu temsil ettiği iddia edilebilirken Külprensi her ne kadar toplumsal cinsiyet kalıpları çerçevesinde kurguyu değiştirmiş olsa da hiyerarşik yapıyı yeniden üretmektedir.

İkili karşıtlıklarla şekillenen karakter temsilleri ile ataerkil ideolojide erkeksi kabul edilen özellikler olumsuzlanırken onun karşısında konumlandırılan belli bir fiziksel standardın öne çıkarılması, bir perinin yardımı olmadan karakterin harekete geçememesi, tesadüfler eşliğinde prens ile prensesin birbirlerini bulması, evlilikle beraber statü atlanarak mutlu bir yaşam sürülmesi ve prensesin isteğiyle perinin kötü kalpli kardeşleri sonsuza dek ev perilerine dönüştürmesi, olumsuz bir durumun eşcinselliğe ait özelliklerle kurgulanması ve işler arasında yaratılan hiyerarşinin sürdürülmesi; Külprensi'nin orijinal masalla benzer bir yapıyı ürettiğinin göstergeleridir. Yüzeyde birtakım parodik ve ironik değişimler yaşansa bile derinde hegemonik söylemler sürdürülmekte ve dönüşüm meselesi kadın-erkek, iri-sıska gibi ikili karşıtıklar düzeyinde kalmaktan öteye geçememektedir.

Külprensi'nin aksine ondan ilham alınarak yazılan/resimlenen diğer eserde, kullanılan anlatı stratejileriyle beraber öncel metin hatırlatılarak klasik masalın dayandığı tüm temeller sarsılmaktadır. Vejetaryen Külkedisi'nin toplumsal cinsiyet ve cinsellik konularında indirgeyici ve kuralcı tutumlara paralel şekilde edebiyatın kalıplara dayalı türlerinden biri olan çocuk edebiyatı örüntüsünü yıkarak yeni ifade olanaklarının önünü açtığını, alternatif bir yapı ve dil kullanarak farklılıkları görünür kıldığını iddia etmek mümkündür. Dolayısıyla eril özelliklerle kurgulanan çocuk edebiyatının geleneksel anlatı kalıpları sarsılarak tür yapıbozuma uğratılmakta ve yeni olasılıklara alan açılmaktadır.

Çalışmada incelenen iki yeniden yazımın özellikle cinsiyet ve cinsellik iletileri hususunda öncel metinden belirgin sapmalar göstermesinin sebebi, dünya çapında çocuk edebiyatı odağında yapılan toplumsal cinsiyet çalışmalarının farkındalık 
seviyesindeki artıştır. Edebiyatta çocuklar üretilen cinsiyetlendirilmiş bedenlerin ve davranışların temsili, gittikçe daha fazla önem arz eden bir konudur. Ataerkil cinsiyet stereotiplerini yıkma ve toplumsal cinsiyet kategorilerini doğal olmaktan ziyade toplumsal olarak üretilen şeklinde ortaya çıkarma projesi, artan bir ivmeyle devam etmektedir. Yazarlar ve çizerler feminist ilkeleri; kadınsı failliği teşvik etme, cinsiyet ve cinselliğin normatif yapılarını sorgulama arzularında görünür kılmaktadır. Bahsi geçen görünürlükle beraber öncel metnin kurgusunu anıştırıp bilinirliğinden/ününden yararlanan ama ona antitez(ler) üreten kurmaca eserler ile bu eserler üzerine yapılan akademik çalışmaların hem nitelik hem de nicelik anlamında artışı kaçınılmazdır.

Bu çalışma, Külkedisi masalının resimli kitap türünde değerlendirilen iki yeniden yazımında toplumsal cinsiyet klişelerini dönüştürmeye yönelik bir kurgu denendiğini öne sürse de daha ileri çalışmaların yapılması önerilmektedir; çünkü cinsiyet ve cinsel yönelim konularındaki sorunlar hâlâ geçerlidir. Çocuk edebiyatının cinsiyetçi yapısı ile bütün kimliklerin ikiliklere mahkûm edilen kurgusunun değişmesi için araştırmalar yapılmalı ve çocuklar için özerk anlayışları benimseyen kitapların yazılması desteklenmelidir. Bununla beraber Millî Eğitim Bakanlığı tarafından öğretim programlarına dâhil edilen eserler, cinsiyet temsilleri bakımından incelenmeli ve elde edilen veriler doğrultusunda yayıncı, eğitimci ve ebeveyn işbirliğiyle gerekli düzenlemeler yapılmalıdır.

\section{Hakem Değerlendirmesi: Dış bağımsız.}

Çıkar Çatışması: Yazarlar çıkar çatışması bildirmemiştir.

Finansal Destek: Yazar bu çalışma için finansal destek almadığını beyan etmiştir.

Peer-review: Externally peer-reviewed.

Conflict of Interest: The authors have no conflict of interest to declare.

Grant Support: The authors declared that this study has received no financial support.

\section{Kaynakça}

Adams, C. J. (2021). Etin cinsel politikası: Feminist-vejetaryen eleştirel kuram (G. Tezcan ve M. E. Boyacıoğlu, Çev.). İstanbul: Ayrıntı Yayınları.

Agvan, Ö., Asutay, H. (2018). Bir anti-masal örneği olarak cam ayakkabıları reddeden Vejetaryen Külkedisi. Humanitas, 6(11), 225-238.

Baykal, N. (2012). Murathan Mungan'ın "Zamanımızın Bir Külkedisi”ni marksist kuram çerçevesinde okumak. Milli Folklor, 24, 137-147. 
Bottigheimer, R. B. (2009). Grimm's bad girls \& bold boys: The moral and social vision of the tales. New Haven: Yale University.

Brothers Grimm (1812, 1819). Aschenputtel. In Household stories by the Brothers Grimm. (L. Crane, Çev.). Project Gutenberg.

Cole, B. (2016). Külprensi (C. Şenkaya, Çev.). İstanbul: Kuraldışı Yayıncılık.

Dowling, C. (1994). Sindrella kompleksi: Çağdaş kadında bağımsızlık korkusu (S. Budak, Çev.). Ankara: Öteki Yayınevi.

Fessler, D. M. T., Arguello, A. P., Mekdara, J. M., Macias, R. (2003). Disgust sensitivity and meat consumption: A test of an emotivist account of moral vegetarianism. Appetite, 41, 312-341.

Fox, N. J. (2002). Refracting health: Deleuze, Guattari and body/self. Health, 6(1), 347-364.

Fox, N. J., Ward, K. (2008). You are what you eat? Vegetarianism, health and identity. Social Science \& Medicine, 66(12), 2585-2595.

Hourihan, M. (1997). Deconstructing the hero: Literary theory and children's literature. New York: Routledge.

Kenyon, P. M., Barker, M. E. (1988). Attitudes towards meat eating in vegetarians and non-vegetarian teenage girls in England - an ethnographic approach. Appetite, 30(2), 185-198.

Lang, A. (1889). The blue fairy book. London: Longmans, Green, and Co.

Lea, E., Worsley, A. (2001). Influences on meat consumption in Australia. Appetite, 36(2), 127-136.

Lopez, N. (2017). Vejetaryen külkedisi (Myriam Cameros, Res.), (Zekine Sanchez Veiga, Çev.). İstanbul: NotaBene Yayınları.

Moebius, W. (1988). Words and pictures. New York: Farrar Straus Giroux.

Mulvey, L. (2014). Görsel zevk ve anlatı sineması. A. Antmen, (Ed.), Sanat/ cinsiyet sanat tarihi ve feminist eleştiri içinde (s. 277-295). (E. Soğancılar, A. Antmen, Çev.). İstanbul: İletişim Yayınları.

Orme, J. (2016). "I'm sure it all wears off by midnight": Prince Cinders and a fairy's queer invitation. In M. H. Dutheil de la Rochère, G. Lathey, M. Wozniak (Eds.), Cinderella across cultures: New directions and interdisciplinary perspective (pp. 215-231). Detroit, Michigan: Wayne State University Press.

Perrault, C. (1697). Cendrillon, ou la petite pantoufle de verre. Histoires ou contes du temps passé, avec des moralités: Contes de ma mère l'Oye. Paris.

Tüfekçi Can, D. (2014). Çocuk edebiyatı: Kuramsal yaklaşım (1. bs). Konya: Eğitim Yayınevi.

Twigg, J. (1979). Food for thought: Purity and vegetarianism. Religion, 9, 13-35.

Wilkie, C. (1999). Relating texts: Intertextuality. In P. Hunt (Ed.), Understanding children's literature (pp. 130-138). London, New York: Routledge. 